\title{
Determinant Factors of Dividend Payments in Brazil
}

Cristiano Augusto Borges Forti

Universidade Federal de Uberlândià, Faculdade de Gestão e Negócios, Uberlândia, MG, Brazil

Fernanda Maciel Peixoto

Universidade Federal de Uberlândia, Faculdade de Gestão e Negócios, Uberlândia, MG, Brazil

Denis Lima e Alves

Universidade Fęderal de Uberlândia, Faculdade de Gestão e Negócios, Uberlândia, MG, Brazil

Received on 12.11.2013 - Desk Acceptance on 01.03.2014 - $3^{\text {rd }}$ version accepted on 01.08.2015

\begin{abstract}
This study identifies factors that shaped cash disbursement distribution policies employed by Brazilian public companies listed on the Brazilian Securities, Commodities and Futures Exchange (BM\&FBOVESPA) from 1995 to 2011. Relationships between Dividends/Total Assets and potential determinants discussed in the literature, including firm size, corporate governance, profitability, leverage, market to . book, liquidity, investment, risk, profit growth, information asymmetry and agency conflict, are examined. The following econometric methods are employed: (1) Tobit, given the nature of the dividend data, and (2) the Generalized Method of Moments (GMM) to control for endogenous regressors. Significant positive variables found include size, return on assets (ROA), market to book, liquidity and profit growth. It can thus be inferred that larger firm size, profitability, market value, liquidity and profit growth correlate with greater firm propensity to distribute money to shareholders, thus supporting the theory of corporate finance. Significant negative variables found include leverage, liquidity squared, capex, beta and tag along 100\%. It is thus inferred that more significantly leveraged companies that invest more heavily in fixed assets and that exhibit high liquidity, higher risk and less conflict between controlling and minority shareholders will be less likely to pay dividends to shareholders.
\end{abstract}

Keywords: dividend policy, corporate finance, brazilian companies. 


\section{INTRODUCTION}

Dividend policies vary widely across companies and sectors, and their effect on company value remains inconclusive among finance researchers. In conjunction with investment and financing policies, dividend policies form one of the three most important areas of decision making in corporate finance. Identifying factors that determinant firm cash distribution and cash holding decisions is of critical importance to financial managers, investors and market regulatory bodies.

Which factors determinant dividend distribution policies employed by Brazilian public companies listed on the BM\&FBOVESPA? In this article, we seek to answer this question by examining factors that may shape such corporate decisions. This study thus identifies, among determinant factors of cash disbursement distribution presented in relevant literature, critical factors in the Brazilian context through a study of the 19952011 period.

Studies on dividend policies in Brazil require specific attention, as incident tax systems on dividends differ from those adopted in the countries examined in most seminal studies on the subject, such as the U.S., England, Germany and Japan. Brazil also employs interest on equity, creating various company tax options for profit distribution. Mandatory minimum dividends may also affect firm dividend payments through legal obligation. Thus, literature on dividends in Brazil seeks to identify the effects of these characteristics on the behaviors of firms and their managers.

The heterogeneity of the Brazilian landscape serves as a research opportunity, enabling one to identify unique tax and legislation variants when evaluating mechanisms of cash distribution to shareholders. We thus examine overall cash distribution trends rather than dividends or interest on equity, as motivations behind distribution through one form or another are not a focus of this study ${ }^{1}$.

Most empirical studies on this topic in the context of Brazil have not employed econometric methodologies adjusted to the sampling distribution of dividen$\mathrm{ds}^{2}$. Following Heineberg and Procianoy's (2003) study, which examined determinants of cash disbursement policies employed in Brazilian firms from 1994 to 2000, we further knowledge of national company dividend policies based on a broader set of variables, accounting for characteristics of the Brazilian legal environment and employing robust econometric approaches to dividend sampling.

Using Economática, BM\&FBOVESPA and Brazilian Securities Commission (CVM) data, all activity sectors are analyzed with the exception of the financial sector given its capital structure peculiarities and restricted and differentiated regulations.

The present study is novel in that it (a) employs the Dividends/Total Assets ratio as a dependent variable rather than the Dividends/Net Income ratio ${ }^{3}$, as total assets are more stable than earnings and dividend flows (Lintner, 1956); (b) broadens the scope of independent variables, which include firm size, corporate governance, return, leverage, market value, liquidity, investments, risk, growth, ownership concentration, agency conflicts and signaling; and (c) compares the results of Tobit and GMM calculations.

The focus on this study is justified given the evident association between dividend policies and nearly all other organizational financial decisions. Decisions regarding the volume of distributed funds affect leverage, the volume of investments, the volume of available cash, mergers and acquisitions, and other factors. Thus, understanding this policy can help elucidate other decisions that companies make, such as those related to capital structures, asset pricing and capital budgets, while also introducing a new perspective on corporate finance and on the protection of minority shareholders.

According to the results of this study, the distribution of funds to shareholders by the Brazilian companies examined follows classical theories of finance, where (a) firm size, returns, market to book, liquidity, control and profit growth exhibit significant positive relationships with the propensity for companies to pay dividends and (b) leverage, corporate governance, risk and information asymmetry exhibit significant negative relationships with dividend payments.

The article is structured as follows. Section 2 provides a theoretical review of Brazilian and international studies on firm dividend policies. Section 3 presents the study research methodology, section 4 describes the study results, and section 5 presents conclusions.

\section{LITERATURE REVIEW}

Among pioneering studies on corporate dividend trends, Lintner (1956) conducts his studies over two phases: (a) an initial phase involving interviews with the Chief Executive Officers (CEOs) of 28 large U.S. 
companies and (b) an empirical phase that involves examining panel data for the companies studied and evaluating dividend trends via econometric models.

Among other findings, Lintner (1956) states that shareholders prefer the stability of dividends and that the market rewards company shares with stability or an increasing (gradual) rate of dividends. Moreover, Lintner (1956) observes that managers use current earnings to determine when dividends must change. In addition, the author found that managers first define dividend policies and that other policies on issues such as investments, debts and cash holdings are defined based on a given volume of dividends. In short, the author found that managers of U.S. firms view dividends as a reflection of profit growth sustainability.

A number of years later, Miller and Modigliani (1961) showed that the distribution of dividends is irrelevant to determining a company's value in the absence of market imperfections and that this value should be influenced only by firm investment decisions. Since this conclusion was made, the majority of studies on dividends have sought to address various market imperfections that affect dividend policies, such as taxes, agency costs, information asymmetries, clientele effects and behavioral models. Studies on this topic are thus concerned with the "Dividend Puzzle" first coined by Black (1976).

The majority of studies on dividends have since examined the following: (a) Tax effects: potential relationships are sought between payment forms and shareholder preferences based on their tax situation (Miller \& Scholes, 1982); (b) Risk effects: it is argued that dividends can alter a company's value due to uncertainties surrounding future firm cash flow delivery (Gordon, 1963; Black \& Scholes, 1974); (c) Clientele effects: it is argued that all companies can attract specific types of investor depending on the way profits are distributed (Miller \& Modigliani, 1961; Black \& Scholes, 1974); (d) Effects of agency costs: it is argued that shareholders must encourage the distribution of available funds to reduce free cash flows at the manager's disposal (Jensen \& Meckling, 1976; Moh'd, Perry \& Rimbey, 1995); and (e) Effects of information asymmetries: such effects are based on dividend policy informational content used by the company (Grullon, Michaely \& Swaminathan, 2002).

Rozeff (1982) examined dividend payment effects and developed a payout ratio model that is consistent and robust for use in both time periods and in different sectors of the economy. In his model, Rozeff (1982) identifies five significant variables that generate expected behaviors: (a) beta, (b) percentage of insider ownership, (c) growth rate of past earnings, (d) growth rate of predicted profits and (e) number of common shareholders. Dickens, Casey and Newman (2002) similarly argue that explanatory factors of dividends must be considered, as the intrinsic model of asset valuation maintains that sto- ck prices are determined by present dividend values.

Kania and Bacon (2005) also suggest that dividends serve as an indicator of a company's present and future performance, even of its potential susceptibility to risk. The authors found significant positive associations between payout and profit growth and debt. By contrast, they found significant negative relationships between payout, risk, Capex, insider ownership and liquidity.

The existence of insider ownership and the number of common shareholders in dividends models spurred research on the relationship between dividend policies and mechanisms of corporate governance. Such studies include Dalmatius and Corrar (2007), Setia-Atmaja, Tanewski, and Skully (2009), Jo and Pan (2009) and Holland and Coelho (2012). Dalmácio and Corrar (2007) studied the relationship between shareholder control concentrations and the dividend policies of 438 Brazilian companies listed on the São Paulo Stock Exchange (Bolsa de Valores de São Paulo - BOVESPA) from 1998 to 2005. The authors found that an increase in shareholder concentration raises the value of dividends paid per share.

Setia-Atmaja et al. (2009) examined whether public family companies in Australia use dividends, debts and board structures to exaggerate or minimize agency problems between controlling and minority shareholders in capital market environments with high investor protection and private control benefits. The authors found that relative to companies not controlled by families, family businesses employ higher dividend payout rates and lower levels of board independence.

Following this line of inquiry, Jo and Pan (2009) examined the relationship between managerial entrenchment and dividend policies for U.S. industrial firms from 1990 to 2003. The authors adopted Logit and Tobit estimators to measure managerial entrenchment via Gompers, Ishii, and Metrick's (2003) G index of governance. They found that firms with entrenched managers are more likely to pay dividends and that doing so lowers cash holdings, thus rendering firms more vulnerable to hostile takeovers.

In examining publicly traded Brazilian firms for the period of 1998 to 2010, Holanda and Coelho (2012) studied whether characteristics external to the company that are representative of the clientele effect differentiate company dividend policies. The authors adopted logistic regression and Tobit methods to determine whether an association exists between decisions to declare dividends and clientele effects. Ownership concentrations were found to most heavily affect earnings distribution policies among the companies studied.

It is important to clarify that the U.S. - which most theories and studies on this subject are based on - employs different tax laws than Brazil with regards to dividend policy. Brazilian legislation on the matter differs in that (a) shareholder dividend receipt does not generate taxes ${ }^{4}$; (b) mandatory minimum dividends are 
employed; and (c) interest on equity that is deductible from the profit tax base of the distributing company, but which generates taxes for receiving shareholders, is used an additional avenue of funds distribution.

Thus, studies on dividend policies of Brazilian companies adapt models employed by international authors to the context of Brazilian legislation and macroeconomics. Such studies have examined tax issues ${ }^{5}$ (Brito \& Rietti, 1981), the volume and frequency of dividend payments (Heineberg \& Procianoy, 2003), the impact of mandatory minimum dividends (Paiva \& Lima, 2001; Martin \& Novaes, 2012), dividend effects on investments (Martins \& Novaes, 2012), clientele effects (Holanda \& Coelho, 2012), share repurchasing (Gabrielli \& Saito, 2003), the effects of dividend payment announcements (Novis Neto \& Saito, 2003), the use of pecking order theory (Brito \& Silva, 2005), and effects on interest on equity (Paiva \& Lima, 2001), among others.

Regarding the determinants of dividend payments, studies by Heineberg \& Procianoy (2003) and Fonteles, Peixoto, Vasconcelos, \& De Luca (2012) are notable. Hei- neberg \& Procianoy (2003) sought to identify determinants of the cash disbursement policies ${ }^{6}$ of public Brazilian companies for 1994 to 2000 . The authors found that profit and cash disbursement in the previous year have the strongest effect on cash disbursement in a given year.

Fonteles et al. (2012) examined the profiles of firms belonging to the Dividend Index (Índice Dividendos - IDIV) of the BM\&FBOVESPA and studied potential determinants of high dividend policies. The study sample included 35 companies registered under the IDIV portfolio in October of 2011. Employing Bird in Hand and Signaling Theories, the authors evaluated eight variables central to dividend policies, namely, shareholder control concentration, cash flow, company size, activity sector, listing segment, institutional capital, and distributed profit and growth. These variables were grouped under four categories: 1 - Concentration; 2 - Profitability; 3 - Prosperity; and 4 - Sector. The authors found dividend policies determined by law to be the ones observed by most companies.

Table 1 presents factors cited in the literature that may influence dividend behaviors.

\section{Table 1 Summary of factors that influence dividend payments}

\begin{tabular}{|c|c|c|}
\hline Factors & References & Influence on Dividends \\
\hline Growth & $\begin{array}{l}\text { La Porta, Lopez-De-Silanes, } \\
\text { Shleifer \& Vishny (2000), Mota } \\
\text { (2007) }\end{array}$ & $\begin{array}{l}\text { High growth rates should be reflected in a reduction in dividend payouts, as } \\
\text { managers must finance growth, preferably with their own funds. }\end{array}$ \\
\hline Agency Costs & $\begin{array}{l}\text { Jensen \& Meckling (1976), Rozeff } \\
\text { (1982) }\end{array}$ & $\begin{array}{l}\text { Higher agency costs correlate with higher dividend payouts to mitigate related } \\
\text { conflicts. }\end{array}$ \\
\hline Information Asymmetry & $\begin{array}{l}\text { Grullon, Michaely \& Swaminathan } \\
\text { (2002) }\end{array}$ & $\begin{array}{l}\text { The greater the information asymmetry between managers and shareholders is, } \\
\text { the greater the latter's desire for dividends. }\end{array}$ \\
\hline Risk & $\begin{array}{l}\text { Gordon (1963), Bernardo \& Ikeda } \\
\text { (2013). }\end{array}$ & $\begin{array}{l}\text { Higher risks associated with company cash flows correlate with lower } \\
\text { dividends, as managers must avoid the withdrawal of company funds that may } \\
\text { be needed in the future. }\end{array}$ \\
\hline Control & $\begin{array}{l}\text { Loss \& Sarlo Neto (2003), } \\
\text { Dalmácio \& Corrar (2007) }\end{array}$ & $\begin{array}{l}\text { This involves three factors: (a) companies controlled by holdings should pay } \\
\text { higher dividends, as economic groups face fewer cash flow risks than individual } \\
\text { companies; (b) companies enjoying concentrated shareholder control can } \\
\text { pay fewer dividends if minority shareholder expropriation is present and vice } \\
\text { versa; and (c) companies of greater shareholding dispersion should pay fewer } \\
\text { dividends, as managers tend to protect company funds to secure their own } \\
\text { interests. }\end{array}$ \\
\hline Investments & La Porta et al. (2000), Mota (2007) & $\begin{array}{l}\text { Higher company investment rates correlate with lower dividends, as they drain } \\
\text { company funds needed to finance investments. }\end{array}$ \\
\hline Profitability & Francis, Schipper \& Vicent (2005) & $\begin{array}{l}\text { Companies with higher returns on equity (ROE) should distribute fewer } \\
\text { dividends, as this serves as a better investment option for shareholders. } \\
\text { However, higher ROE companies can make more consistent payments to } \\
\text { shareholders by financing growth while still remunerating shareholders. }\end{array}$ \\
\hline Size & Mota (2007) & $\begin{array}{l}\text { Size and maturity factors can affect dividends. Larger, more mature } \\
\text { companies tend to pay higher dividends than companies that are growing and } \\
\text { consolidating in the market. }\end{array}$ \\
\hline
\end{tabular}

Prepared by the authors.

Factors that affect manager decision of dividends initiation or modification remain unknown. From a review of national and international study results and existing research gaps, this article contributes new em- pirical evidence to the literature on the subject, using appropriate econometric tools to evaluate determinants of firm dividend policies. 


\section{METHODOLOGICAL APPROACH}

A database was compiled from Economática, Securities and Exchange Commission (Comissão de Valores Mobiliários - CVM) and BM\&FBOVESPA data. The first source provided financial statements (balance sheets, income statements, cash flows, statements of sources and applications of funds). The second and third sources provided information on corporate governance and other data such as firm establishment dates. The sample includes annual observations of all companies listed on the BM\&FBOVESPA from 1995 to 2011. The financial sector was excluded, forming a final sample of 300 companies and 3,671 observations for an unbalanced panel with an average of 12.2 observations per company ${ }^{7}$. To correct possible inaccuracies due to extreme observations (outliers), data were winsorized to 0.025 . As noted in Section 1, distinctions were not made between dividend and interest on equity payment amounts. We use cash disbursement and dividends to measure the total of cash distributed to shareholders regardless of payment method used ${ }^{8}$. Variables that may affect dividend policies used on this study are presented below. Formulas and calculations are shown in Table 2.

- Size: Based on the results of previous studies (Renneboog \& Trojanowski, 2011; Moh'd et al., 1995), larger companies are expected to be more likely to pay dividends than smaller companies.

- ROA - Return on Assets: It is expected that more profitable companies will pay higher dividends than others (Kania \& Bacon, 2005; John \& Knyazeva, 2006).

- Leverage: The finance literature largely attributes the relationship between dividends and leverage to signaling effects. An increase in company debt levels would serve as a credible signal that the company anticipates high future cash flows. In this context, managers would pay higher dividends to confirm this signal. Given cause and effect relationships between variables, leverage lagged over one period is employed (Casey \& Dickens, 2000; Jensen, Solberg \& Zorn, 1992). However, other authors claim that there is an inverse relationship between leverage and payout. Therefore, in principle, the expected sign of leverage cannot be determined.

- Market to Book: Markets are expected to identify companies that offer superior present and future cash flows to shareholders (Speranzini, 1994). A positive sign is anticipated.

- Liquidity: Represents a company's overall liquidity level. Companies with greater liquidity offer more security so that managers can maintain or even increase dividend payout levels. A positive sign is thus anticipated (Acharya \& Viswanathan, 2011).
- Liquidity': This variable is intended to account for non-linear liquidity behaviors in two respects. First, firms with higher levels of liquidity may reach this level through dividend restrictions. Second, there may be a threshold at which liquidity maintenance begins to restrict dividend payments. Hence, a negative sign is expected (Acharya \& Viswanathan, 2011).

- Capex: This refers to the investment or growth rate of firm fixed assets. Companies engaging in numerous investments are typically required to retain profits to finance investments without altering debt levels. Therefore, a negative sign is anticipated (La Porta, Lopez-De-Silanes, Shleifer \& Vishny, 2000; Mota, 2007).

- Beta: Indicates the systematic risk of a firm. As managers are reluctant to increase dividends in the present and must reduce them in the future (Lintner, 1956), companies facing greater risks are assumed to be more reluctant to pay high dividends. A negative sign is thus anticipated (Rozeff, 1982; Bernardo \& Ikeda, 2013).

- Profit Growth: Managers support an increase in dividends when guaranteed higher future cash flows (Lintner, 1956). Companies exhibiting higher levels of profit growth should mitigate uncertainties facing managers and pay more dividends. A positive sign is anticipated (Francis, Schipper \& Vicent, 2005).

- Adherence to the BM\&FBOVESPA's Distinctive Levels of Corporate Governance (Níveis diferenciados de Governança Corporativa - NDGC): BM\&FBOVESPA has four distinctive listing segments for companies that agree to undertake voluntary corporate rules on each segment such as issue only common shares, exhibit greater levels of transparency and employ minimum free float policies. It is hypothesized that such companies pay lower dividends than those belonging to the traditional market (Fonteles, Peixoto, Vasconcelos \& De Luca, 2012; Holland \& Coelho, 2012). The dummy for the "traditional" segment was not included in the model to serve as a basis for comparison with other governance variables and to avoid the "dummy variable trap." Therefore, a negative sign is anticipated for all levels of governance.

- 100\% Tag Along: Companies with this voluntary concession mitigate agency conflicts between controlling and minority shareholders. Giving minority shareholders better co-sale rights than required by law, allows a reduction on the demand for dividends by them (Grullon et al., 2002).

- Poison Pill: Companies employing a poison pill clause exhibit more dispersed shareholding tendencies. Dispersed shareholding patterns correlate with less shareholder power over managers. It is thus necessary 
to maintain lower dividends to enjoy private benefits of control. A negative sign is anticipated (Vieira, Martins \& Fávero, 2009).

- (Dividends/Total Assets): This is the dependent variable. It is calculated by dividing the sum of dividends and interest on equity by the total assets (Mayne, 1980). It represents the relative level of cash flows distributed to shareholders. The choice of Total Assets (TA) denominator instead of the profit was due to the high variation of the latter that is not always accompanied by a change in dividends? . Using TA as a denominator prevents the development of non-existent variations in the dependent variable, as dividends behave in a more linear trend over time (Lintner, 1956) ${ }^{10}$.

Data on the variables presented above were available for all companies included in the sample. Additional variables were collected to identify the characteristics of companies that pay higher or lower dividends. However, these variables were obtained for a random sample of 102 companies of the 300 firms included in the original sample. The following additional variables were used:

- Age: More mature companies tend to exhibit more stable cash flows. Age is also related to more heavily consolidated products and processes, and also with shareholders with more forceful demands on the distribution of cash flows. A positive sign is anticipated (Gu, Lee \& Rosett, 2005).

- Majority Control: Companies with a defined controller, whether through a shareholder agreement or through the concentration of sufficient common shares for shareholder control of the company. In such cases, the majority shareholder has greater power over the managers in the definition of dividends. A positive sign is anticipated (Dalmácio \& Corrar, 2007).

- CEO \& BD: Companies in which the CEO and Chairman of the Board of Directors are the same person. This may suggest the existence of two factors that increase the probability of higher dividends: (a) the CEO and President are the same person, and typically, this CEO is also the main shareholder of the company; (b) this may reflect low corporate governance (CG) quality, requiring the payment of higher dividends to shareholders to mitigate conflicts between shareholders (Hermalin \& Weisbach, 2003). A positive sign is thus anticipated when no separation of duties is present (Almeida, 2012).

Based on the variables presented, two econometric models were assembled: the first covers variables available for all companies, and the second extended model includes additional variables but fewer observations.

Model 1: Dividends/Total Assets ${ }_{\mathrm{i}, \mathrm{t}}=\alpha+$ Size $_{\mathrm{i}, \mathrm{t}}+R O A_{\mathrm{i}, \mathrm{t}}+$ Leverage $_{\mathrm{i}, \mathrm{t}-1}+$ Market toBook $_{\mathrm{i}, \mathrm{t}}+$ Liquidity $_{\mathrm{i}, \mathrm{t}}+$ Liquidity $_{\mathrm{i}, \mathrm{t}}+$

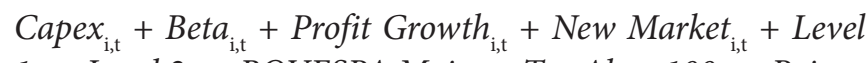
$1_{\mathrm{i}, \mathrm{t}}+$ Level $_{\mathrm{i}, \mathrm{t}}+$ BOVESPA Mais $\mathrm{i}_{\mathrm{i}, \mathrm{t}}+$ Tag Along100 ${ }_{\mathrm{i}, \mathrm{t}}+$ Poison Pills $_{\mathrm{i}, \mathrm{t}}+S_{\mathrm{i}}+d_{\mathrm{t}}+\varepsilon_{\mathrm{i}, \mathrm{t}}$

Extended Model 1: Dividends/Total Assets $s_{\mathrm{i}, \mathrm{t}}=\alpha+$ Size $_{\mathrm{i}, \mathrm{t}}$ $+R O A_{\mathrm{i}, \mathrm{t}}+$ Leverage $_{\mathrm{i},-\mathrm{1}}+$ Market toBook $_{\mathrm{i}, \mathrm{t}}+$ Liquidity $_{\mathrm{i}, \mathrm{t}}$ + Liquidity $_{\mathrm{i}, \mathrm{t}}^{2}+$ Capex $_{\mathrm{i}, \mathrm{t}}+$ Beta $_{\mathrm{i}, \mathrm{t}}+$ Profit Growth $_{\mathrm{i}, \mathrm{t}}+$ New Market $_{\mathrm{i}, \mathrm{t}}+$ Level $_{\mathrm{i}, \mathrm{t}}+$ Level $_{\mathrm{i}, \mathrm{t}}+$ BOVESPA Mais $\mathrm{i}_{\mathrm{i}, \mathrm{t}}+$ Tag Along100 ${ }_{\mathrm{i}, \mathrm{t}}+$ Age $_{\mathrm{i}, \mathrm{t}}+$ PoisonPills $_{\mathrm{i}, \mathrm{t}}+$ MajControl $_{\mathrm{i}, \mathrm{t}}+$ $C E O \& B D_{\mathrm{i}, \mathrm{t}}+S_{\mathrm{i}}+d_{\mathrm{t}}+\varepsilon_{\mathrm{i}, \mathrm{t}}$

$i$ and $t$ represent the company and year, respectively. $\alpha, S, d$ and $\varepsilon$ represent the intercept, sector dummies, year dummies and error term, respectively. Definitions, formulas, and expected signs for the variables used are presented in Table 2.

The fact that cash disbursement values are equal to zero in $34 \%$ of the sample observations interferes with the study methodology. In addition, values of zero are omitted, i.e., companies experiencing financial difficulty cannot raise funds in the form of negative dividends. The Tobit method was thus used, following methods presented by Barclay, Smith, \& Watts (1995) and Dickens et al. (2002).

Regression assumptions of heteroscedasticity, normality, and multicollinearity were treated as follows: the first with White's (1980) matrix to yield robust error values; the second with an analysis of possible correction variables via logarithmic transformation; and the third with variance inflation analyses of regressions that did not generate any variable with a value exceeding five, where the literature indicates a value 10 as the limit.

OLS (Ordinary Least Squares) and Panel (Fixed Effects and Random Effects) models do not appear to be adequate when using numerous observations that are equal to zero and omitted data, as in the case of dividends. Their use can generate underestimated and inconsistent coefficients. However, the Tobit method performs adequately under such conditions (Barclay, Smith \& Watts, 1995).

The Tobit method is suitable for samples with 30\% or more observations censored. As $34 \%$ of the sample observations fall under this category, the Tobit method is the most appropriate one in this case. Specification tests for the Tobit model show that the model is consistent and that estimators differ from zero at a significance level of $1 \%$.

Nevertheless, one of the most significant econometric problems faced in studies on corporate finance concerns issues of endogeneity. ROA, Leverage, Payout, Liquidity and Capex variables are difficult to control for effects of reverse causality. Such variables are understood as a result of simultaneous business decisions, and thus, it is difficult to identify cause-and-effect relationships between them (Barros, Junior, Silveira \& Bergmann, 2010). The Generalized Method of Moments

Some companies distribute dividends even when experiencing losses. In such cases, while dividends are positive, payouts will become negative through division with a negative value, diametrically changing the regression results. Employing total assets as a denominator eliminates this bias.

The coefficient of variation (CV) of the variable (Dividends/Profit) is 35 times greater than the CV of the variable (Dividends/Total Assets) for the sample used in the present study. The CV is a statistical measure of dispersion that is suitable for comparing data dispersion levels over several scales. 
(GMM) method can be employed to address endogeneity problems in corporate finance data. The GMM allows all model regressors to remain endogenous yet is still able to generate robust and efficient coefficients. However, the GMM method is not preferred when examining data that include numerous observations equal to zero.

The two methods (Tobit and GMM) can thus be used together to calculate coefficients of the proposed regression model, as each improves the reliability and robustness of the results in unique ways. In addition, it is anticipated that the results will be similar regardless of econometric methods used, suggesting that the proposed model of dividend payments is consistent.

From this methodological rigor, our use of numerous approaches, our treatment of variables and our inclusion of all relevant variables, we argue that this study contributes to the literature on dividends in Brazil. In addition, a robustness test was performed on the issue of mandatory dividends, which can introduce bias if not properly treated.

Table 2

Description of regression variables

\begin{tabular}{|c|c|c|c|}
\hline Variable & Expected Sign & Description & Operational Definition \\
\hline Size & $(+)$ & Company size & Natural logarithm of the company's total assets. \\
\hline ROA & $(+)$ & Return on assets & $\begin{array}{l}\text { Operating profit (before financial expenses) divided by total assets } \\
\text { of the company. }\end{array}$ \\
\hline Leverage & $(+/-)$ & Company debt & Total liabilities divided by shareholder equity. \\
\hline Market to Book & $(+)$ & Market to book & Adjusted market value divided by the book value of the company. \\
\hline Liquidity & $(+)$ & Company liquidity & Current assets divided by current liabilities. \\
\hline Liquidity $^{2}$ & $(+)$ & Liquidity squared & Company liquidity squared. \\
\hline Capex & $(-)$ & Investment rate in fixed assets & Growth rate of fixed assets. \\
\hline Beta & $(-)$ & Systematic risk & Company beta drawn from Economática. \\
\hline Profit Growth & $(+)$ & Growth rate of profits & Current profits minus previous profits divided by previous profits. \\
\hline $\begin{array}{l}\text { Dividends/Total } \\
\text { Assets }\end{array}$ & & $\begin{array}{l}\text { Cash disbursement paid in relation to the } \\
\text { total assets of the company }\end{array}$ & $\begin{array}{l}\text { Cash payments to shareholders divided by total assets. Dependent } \\
\text { variable. }\end{array}$ \\
\hline Age & $(+)$ & Company age & $\begin{array}{c}\text { Number of years between company establishment and data } \\
\text { observation. }\end{array}$ \\
\hline Governance Levels & $(-)$ & $\begin{array}{l}\text { BM\&FBOVESPA } \\
\text { level of governance }\end{array}$ & $\begin{array}{l}\text { Five dummy variables with a value of one for the respective level } \\
\text { of governance and with a value of zero for the others. The levels } \\
\text { are New Market, Level 1, Level 2, BOVESPA Mais and Traditional } \\
\text { The traditional variable was omitted from the model to disable the } \\
\text { "dummy variable trap". }\end{array}$ \\
\hline Poison Pills & $(-)$ & Company has poison pills & $\begin{array}{l}\text { Dummy variable with a value of one for firms employing a poison } \\
\text { pills clause in their bylaws. }\end{array}$ \\
\hline Maj. Control & $(+)$ & Company has majority control & $\begin{array}{c}\text { Dummy variable with a value of one for companies that have a } \\
\text { majority controller and with a value of zero to indicate dispersed } \\
\text { shareholding. }\end{array}$ \\
\hline
\end{tabular}

Note: This table presents the regression variables. The first column lists terms used in econometric models, the second lists the hypothesized sign, the third describes the variable, and the fourth presents operational definitions.

\section{RESULTS}

Table 3 presents descriptive statistics for model 1 variables categorized into three groups: companies that do not pay dividends, companies that pay moderate dividends and companies that pay high dividends. Companies that do not pay dividends are smaller, less profitable, have a market value lower than book value and exhibit low liquidity and greater risk. Companies that pay high dividends are larger and more heavily leveraged and present average liquidity levels and lower profit growth rates. The highest market value is associated with moderate dividends, supporting the notion that the market pays a premium for dividend payments and that very high dividends may signify a lack of investment options. 
Table 3

Descriptive statistics of the variables

\begin{tabular}{lcccc}
\hline & Payout $=0$ & $0<$ Payout $<0.7$ & Payout $>0.7$ & All \\
\hline Number of Companies & 92 & 166 & 42 & 300 \\
Mean Total Assets (M.M.) & 1.369 & 5.702 & 7.463 & 4.475 \\
Mean ROA & -.0136 & .0872 & .0779 & .0519 \\
Mean Leverage & 2.00 & 1.69 & 2.34 & 1.88 \\
Mean Market to Book & .862 & 1.688 & 1.416 & 1.373 \\
Mean Liquidity & 1.32 & 2.06 & .1 .64 & 1.76 \\
Mean Capex & .245 & .229 & .165 & .225 \\
Mean Beta & .94 & -.16 & .87 & .80 \\
Mean Profit Growth & -.31 & & -.56 & -.26 \\
\hline
\end{tabular}

Source: Study results.

Figure 1 presents descriptive statistics for model 1 and extended model 1 categorical variables. A major "time-variant" change is evident, signifying that these variables can help explain dividend variance. The 100\%
Tag Along and variables for the BM\&FBOVESPA levels of governance since 2001 (the year when the system came into force) are noteworthy.

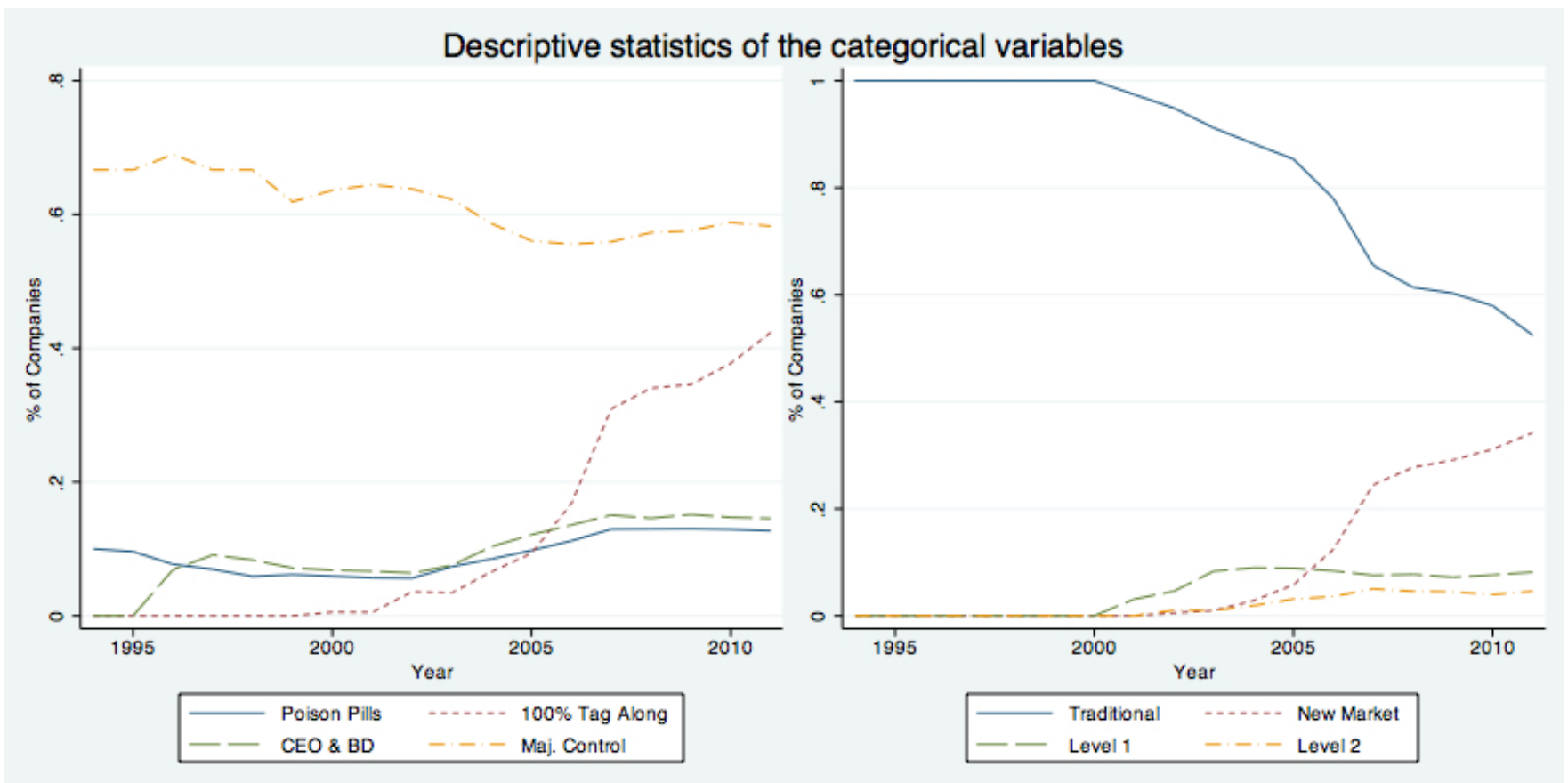

Note: The sample includes all firms listed on the BM\&FBOVESPA from 1995 to 2011, with the exception of financial companies. Values represent the percentage of companies in relation to all companies of the sample for each year. CEO \& BD and Maj. Control variables were evaluated for a sample of 102 companies selected randomly from the full sample.

Figure 1 Descriptive statistics for the categorical variables

Figure 2 presents descriptive statistics for the continuous variables. To conduct a more detailed analysis of dividend policies adopted in the companies, the sample was divided into two subgroups: companies that pay higher dividends and companies that pay lower dividends. The sample was accordingly divided into four quartiles based on Payout/Total Assets relationship. The figure only lists companies of the first and fourth quartiles. The figure shows that companies that pay higher dividends are larger, are more profitable, exhibit higher liquidity, and enjoy higher market value and profit growth trends. 


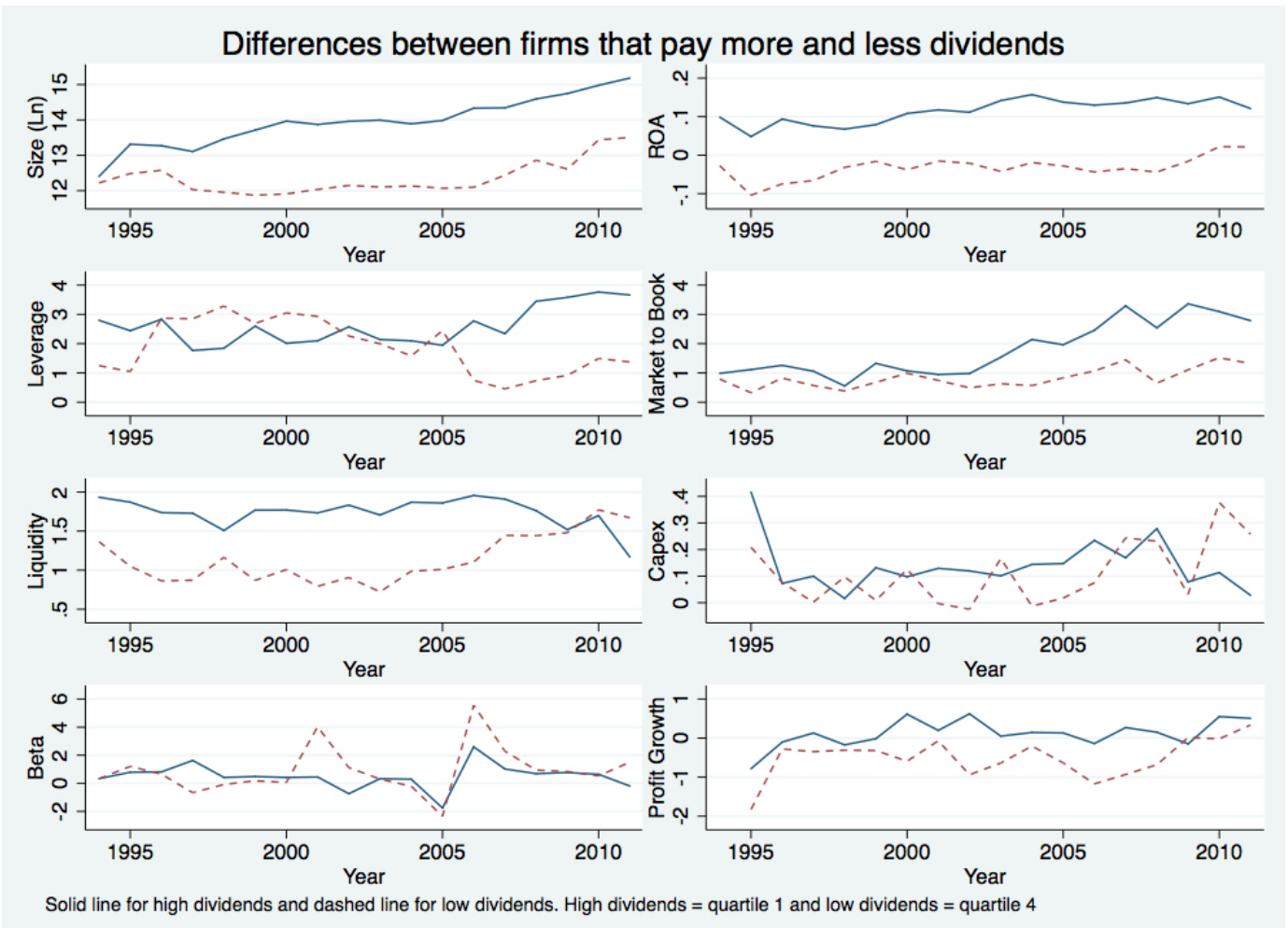

Note: This graph presents descriptive statistics of the continuous variables. For each variables used in the study, a graph was prepared with two lines. One depicts average variable values for companies with high dividends, and the other depicts average variable values for companies with low dividends. Example: for variable size, the solid line shows the average size of companies with the highest Dividends/Total Assets ratio, and these therefore belong to the first quartile. The dotted line shows the average size of companies belonging to the fourth quartile, and these therefore pay the lowest dividends. The sample includes all firms listed on the BM\&FBOVESPA from 1995 to 2011 with the exception of financial companies.

Figura 2 Descriptive statistics for the continuous variables

Regression results are shown in Table 4. Columns 1 and 2 show the coefficients of model 1 based on Tobit and GMM estimators, respectively. Column 3 shows the coefficients of extended model 1 using Tobit estimators. The coefficients suggest stability between the estimators. No significant coefficient presented conflicting signal when compared to the other methods used. Tobit coefficients, as expected, are higher than GMM coefficients, as the Tobit method more effectively treat values equal to zero. Specification tests including the $\mathrm{F}$ and $\mathrm{Chi}^{2}$ tests did not produce results that invalidate the results, which are discussed below.

Size, ROA, Leverage, Market to Book, Liquidity, Liquidity $^{2}$, Capex, Beta and Profit Growth variables were significant and presented the same sign across all methods and models used. Poison Pills and 100\% Tag Along variables were significant, but not in all variations. All variables with significant coefficients also presented the expected signs according to finance theory, supporting the adequacy of the theoretical model. A ceteris paribus analysis for each variable was conducted: variable Size showed a positive relationship with dividend payments, indicating that larger firms are more likely to pay dividends (Mota, 2007). This variable is also interpreted as an indication of company maturity, suggesting that larger and more mature companies are more likely to pay dividends, as they are not presented with as many opportunities to engage in new investments or are affor- ded access to other funding sources, rendering it unnecessary to retain profits to make such investments.

The ROA, confirming Lintner's (1956) theory, is positive with the highest coefficients. Managers are more inclined to pay dividends when a company enjoys higher profitability and returns on investments. In addition, shareholders themselves expect higher dividends when a company is more profitable.

Leverage was found to be negatively correlated with dividends, indicating that higher company leverage levels in the preceding year correlate with lower dividen$\mathrm{ds}$ in the following year, confirming that an increase in debt serves as a credible sign that a company anticipates high future cash flows (Jensen et al., 1992).

The relationship between Market to Book factors and dividends was found to be significant, presenting a positive sign, as noted in the literature. These results are consistent with those of Lintner (1956), who states that the market pays a premium for shares of companies that pay higher dividends. On the one hand, it is assumed that a company that pays higher dividends is evaluated more favorably in the market, increasing its Market to Book value. On the other hand, it is assumed that such a company would already have exhibited high Market to Book values for other reasons (market shares, signed contracts, patents, etc.) and that the managers of these firms, interested in publicizing firm capacities to contribute future cash flows to the market, will increase their 
dividends. Both hypotheses are plausible and related to publicizing future firm cash generation capacities.

The Liquidity variable was found to be positive and significant, indicating that dividend payments are positively related to fund availability. As profitability is controlled by the ROA variable, liquidity is not affected by the availability of cash provided exclusively by the most profitable companies. Companies that are not as profitable but that are in a comfortable financial situation (high volumes of available cash) pay higher dividends. This may explain Lintner's (1956) observation that managers tend to resist dividend reduction, even when company results are inconsistent.

The Liquidity ${ }^{2}$ variable was found to have a significant negative sign, suggesting that dividend payments decline as liquidity increases. Both the Liquidity and Liquidity $^{2}$ coefficient results suggest the presence of non-linear liquidity behaviors in relation to dividends, and the negative sign of the latter corresponds to a downward sloping line, indicating that maintaining high levels of liquidity entails sacrificing dividends paid to shareholders. This result confirms the existence of an optimal liquidity threshold for dividend payments, beyond which dividends decline as liquidity increases.

The Capex variable was found to be negative, confirming that firms engaged in more investments exhibit lower payout tendencies. The coefficients obtained are robust for all companies included in the sample but may become biased upon evaluation due to (a) the inclusion of companies from various sectors that do not always require Capex investments, potentially affecting sector control variables, and (b) a need for constant investment on the part of Brazilian companies, as Brazil is a developing country.

The Beta variable was found to be negative and significant as expected, indicating that higher risks characteristic of a certain sector correlate with lower firm tendencies to pay dividends (Gordon, 1963; Bernard \& Ikeda, 2013). Coefficients approaching a value of zero do not denote an insignificant variable. Rather, they indicate that beta effects on payout levels are negligible and/or that the scales used are too small.

The Profit Growth variable was found to be positive and significant, indicating that managers use dividends to signal future company profit growth trends, as profitability is controlled by the ROA variable (La Porta et al., 2000; Mota, 2007).

The Poison Pills coefficient was found to have a negative sign, as expected, but without statistical significance. This may suggest that (a) another model variable is affecting the shareholding dispersion or that (b) the most widely dispersed Brazilian companies do not differ significantly from those that are not dispersed in terms of dividend payments.

The 100\% Tag Along variable was also found to be negative, as expected. The variable's consistency suggests that it may wield signaling power in competing with dividends. As the 100\% Tag Along variable for common shares is reflective of a right that can never be exercised by shareholders, it may be adopted to mitigate agency conflicts without entailing the high costs associated with dividend payment.

\begin{tabular}{|c|c|c|c|c|c|c|c|}
\hline \multicolumn{2}{|c|}{ Dependent Variable } & \multicolumn{3}{|c|}{ Dividends/Total Assets } & \multirow{2}{*}{$\frac{\text { Div/Profits }}{(4)}$} & \multicolumn{2}{|c|}{ High Dividends } \\
\hline & Expected & (1) & $(2)$ & (3) & & (5) & (6) \\
\hline & Sign & Tobit & GMM & Tobit(E) & Tobit(2) & Payout $>40 \%$ & Payout $>70 \%$ \\
\hline \multirow[t]{2}{*}{ Size } & $(+)$ & $0.0024^{* * *}$ & $0.0019 *$ & $0.0025^{* * *}$ & $0.1114^{* * *}$ & $0.5318^{* * *}$ & $0.4871^{* * *}$ \\
\hline & & $(5.27)$ & $(1.67)$ & $(2.92)$ & $(12.16)$ & $(6.14)$ & $(5.04)$ \\
\hline \multirow[t]{2}{*}{ ROA } & $(+)$ & $0.1474^{* * *}$ & $0.0789 * * *$ & $0.2315^{* * *}$ & $2.2230^{* * *}$ & $6.0533^{* * *}$ & $4.9924 * * *$ \\
\hline & & $(15.04)$ & $(8.25)$ & $(11.96)$ & $(15.55)$ & $(8.78)$ & $(7.04)$ \\
\hline \multirow[t]{2}{*}{ Leverage (L1) } & $(+/-)$ & $-0.0011^{* * *}$ & $-0.0031^{* * *}$ & $-0.0016^{* * *}$ & $-0.0096 * *$ & -0.0077 & 0.0059 \\
\hline & & $(-5.87)$ & $(-6.44)$ & $(-4.60)$ & $(-2.55)$ & $(-0.48)$ & $(0.36)$ \\
\hline \multirow[t]{2}{*}{ Market to Book } & $(+)$ & $0.0028^{* * *}$ & $0.0031^{* * *}$ & $0.0018^{* * *}$ & -0.0015 & $0.1124^{* * *}$ & $0.0772 *$ \\
\hline & & $(5.81)$ & $(6.01)$ & $(2.75)$ & $(-0.20)$ & $(3.00)$ & (1.95) \\
\hline Liquidity & $(+)$ & $0.0228^{* * *}$ & $0.0083^{* * *}$ & $0.0086^{* * *}$ & $0.5217^{* * *}$ & $1.2718^{* * *}$ & $1.4760^{* * *}$ \\
\hline \multirow[t]{2}{*}{ Liquidity $^{2}$} & $(-)$ & $-0.0026^{* * *}$ & $-0.0009 * * *$ & $-0.0013^{* * *}$ & $-0.0656^{* * *}$ & $-0.1829^{* * *}$ & $0.2119^{* * *}$ \\
\hline & & $(-9.45)$ & $(-3.52)$ & $(-2.61)$ & $(-11.93)$ & $(-6.43)$ & $(-6.47)$ \\
\hline \multirow[t]{2}{*}{ Capex } & $(-)$ & $-0.0032^{* *}$ & $-0.0026^{* *}$ & $-0.0064^{* * *}$ & -0.0085 & 0.1409 & $0.2276^{*}$ \\
\hline & & $(-2.41)$ & $(-2.41)$ & $(-3.16)$ & $(-0.33)$ & $(1.20)$ & $(1.72)$ \\
\hline \multirow[t]{2}{*}{ Beta } & $(-)$ & $-0.0002^{* *}$ & $-0.0002^{* * *}$ & $-0.0004^{* * *}$ & -0.0035 & -0.0083 & -0.0049 \\
\hline & & $(-2.43)$ & $(-2.72)$ & $(-2.78)$ & $(-1.63)$ & $(-1.05)$ & $(-0.59)$ \\
\hline \multirow[t]{2}{*}{ Profit Growth } & $(+)$ & $0.0007^{* * *}$ & $0.0007^{* * *}$ & $0.0009 * * *$ & $0.0169 * * *$ & $0.0663^{* * *}$ & $0.0522^{* * *}$ \\
\hline & & (3.58) & $(5.48)$ & $(2.87)$ & $(4.56)$ & $(4.20)$ & (3.13) \\
\hline
\end{tabular}




\begin{tabular}{|c|c|c|c|c|c|c|c|}
\hline Poison Pills & $(-)$ & $\begin{array}{c}-0.0029 \\
(-1.34)\end{array}$ & $\begin{array}{c}-0.0023 \\
(-0.80)\end{array}$ & $\begin{array}{c}-0.0073^{* * *} \\
(-3.01)\end{array}$ & $\begin{array}{c}-0.0572 \\
(-1.45)\end{array}$ & $\begin{array}{c}-1.0114^{* *} \\
(-2.29)\end{array}$ & $\begin{array}{c}-1.2413^{* *} \\
(-2.25)\end{array}$ \\
\hline 100\% Tag Along & $(-)$ & $\begin{array}{c}-0.0086^{* * *} \\
(-3.95)\end{array}$ & $\begin{array}{c}-0.0075^{* * *} \\
(-3.09)\end{array}$ & $\begin{array}{c}0.0002 \\
(0.09)\end{array}$ & $\begin{array}{c}-0.1533^{* * *} \\
(-2.74)\end{array}$ & $\begin{array}{c}-0.7196^{* *} \\
(-2.39)\end{array}$ & $\begin{array}{c}-1.1989^{* * *} \\
(-3.47)\end{array}$ \\
\hline New Market & $(-)$ & $\begin{array}{c}0.0006 \\
(0.22)\end{array}$ & $\begin{array}{c}0.0019 \\
(0.60)\end{array}$ & & $\begin{array}{c}-0.0484 \\
(-0.75)\end{array}$ & $\begin{array}{c}0.3610 \\
(1.00)\end{array}$ & $\begin{array}{c}0.5363 \\
(1.30)\end{array}$ \\
\hline Level 1 & $(-)$ & $\begin{array}{c}-0.0049^{* *} \\
(-2.40)\end{array}$ & $\begin{array}{c}-0.0036 \\
(-1.26)\end{array}$ & & $\begin{array}{c}-0.1008^{* *} \\
(-2.05)\end{array}$ & $\begin{array}{c}0.1450 \\
(0.50)\end{array}$ & $\begin{array}{c}-0.0197 \\
(-0.06)\end{array}$ \\
\hline Level 2 & $(-)$ & $\begin{array}{c}0.0063^{*} \\
(1.83)\end{array}$ & $\begin{array}{c}0.0052 \\
(1.31)\end{array}$ & & $\begin{array}{c}0.0496 \\
(0.75)\end{array}$ & $\begin{array}{c}0.2504 \\
(0.54)\end{array}$ & $\begin{array}{c}0.6887 \\
(1.30)\end{array}$ \\
\hline BOVESPA Mais & $(-)$ & $\begin{array}{c}-0.0845 \\
(.)\end{array}$ & $\begin{array}{c}0.0329^{* * *} \\
(5.72)\end{array}$ & & $\begin{array}{c}-1.6579 \\
(.)\end{array}$ & $\begin{array}{c}-10.9064 \\
(-0.00)\end{array}$ & $\begin{array}{c}-13.5876 \\
(-0.00)\end{array}$ \\
\hline Age & $(+)$ & & & $\begin{array}{c}-0.0000 \\
(-0.73)\end{array}$ & & & \\
\hline Maj. Control & $(+)$ & & & $\begin{array}{c}0.0041^{*} \\
(1.89)\end{array}$ & & & \\
\hline CEO\&BD & $(+)$ & & & $\begin{array}{c}0.0193^{* * *} \\
(5.76)\end{array}$ & & & \\
\hline Constant & & $\begin{array}{c}-0.0549^{* * *} \\
(-6.92)\end{array}$ & $\begin{array}{c}-0.0389^{* * *} \\
(-2.93)\end{array}$ & $\begin{array}{c}-0.0275^{*} \\
(-1.91)\end{array}$ & $\begin{array}{c}-1.8475^{* * *} \\
(-10.37)\end{array}$ & $\begin{array}{c}-10.673^{* * *} \\
(-5.75)\end{array}$ & $\begin{array}{c}-10.199 * * * \\
(-4.82)\end{array}$ \\
\hline Dummy for Year & & Yes & Yes & Yes & Yes & Yes & Yes \\
\hline Dummy for Sector & & Yes & Yes & No & Yes & Yes & Yes \\
\hline Observations & & 3242 & 3242 & 968 & 3241 & 3242 & 3242 \\
\hline No. of Firms & & 300 & 300 & 102 & 300 & 300 & 300 \\
\hline Log-likelihood & & 3987.25 & & 1512.95 & -2364.10 & & \\
\hline $\mathrm{Chi}^{2}$ & & & 7172.26 & & & 316.57 & 266.69 \\
\hline
\end{tabular}

Note: This table presents Tobit regressions with (1) panel, (2) GMM and (3) extended Tobit model data. The dependent variable is the cash disbursement value divided by Total Assets. Column 4 presents a model equivalent to models 1 and 2 but with the cash disbursement value divided by the Net Income as the dependent variable. Columns 5 and 6 show the results of the Logit regression. High Dividend values serve as the dependent variable in both models. A dummy variable equals one when the Payout (Dividends/Net Income) is greater than or equal to $40 \%$ in model 1 or $70 \%$ in model 2 . This value is equal to zero when the payout value is less than $40 \%$ in model 1 and less than $70 \%$ in model 2. The sample includes all firms listed on the BM\&FBOVESPA from 1995 to 2011, with the exception of companies in the financial sector. Absolute values of coefficient $t$ statistics for the independent variables are presented in parentheses. Significance levels are as follows: ${ }^{*} \mathrm{p}<0.10,{ }^{* *}$ $\mathrm{p}<0.05,{ }^{* * *} \mathrm{p}<0.01$.

The BM\&FBOVESPA Listing Segments did not show consistent signs or significance in relation to the Traditional sector (omitted from the model for comparison). This suggests that participating companies limit information asymmetries through adoption, but their mere presence in these segments does not suggest superior governance to that of companies not present in these segments.

Overall, model 1 identified several factors that affect dividend payments of Brazilian companies listed on the BM\&FBOVESPA. Through this analysis, it was possible to identify factors that affect company tendencies to distribute money to shareholders.

The results of the extended model 1, which includes additional variables, are shown in the third column of Table 4. As noted earlier, the additional variables reduced the number of firms and observations included (from 3,242 observations to 968). However, the Tobit model still maintained the significance of coefficients from model 1. The inclusion of additional variables to this model did not affect the results obtained from the analysis of model 1 . The additional variables instead offer new information on factors that affect dividend payments by Brazilian companies.

The Age variable had no effect on the distribution of dividends. This may be attributable in part to the time at which the company started to show higher growth. Our use of dates when firms went public rather than foundation dates may have also played a role in this outcome.

Maj. Control and CEO\&BD values were significantly positive, as expected. This suggests that companies with a majority controller and those led by a CEO who also serves as a Board of Directors chair offer higher dividend payments. This may be attributable to the fact that (1) such companies typically exhibit tense conflicts between majority and minority cohorts that may be reduced with an increase in dividend payments or (2) the concentration of power is sustained through the concentration of control that can increase dividends, whether through conflicts with minority shareholders or the controllers' cash flow needs.

As a robustness test for the coefficient results found for model 1 and its extended version, an equivalent ver- 
sion of model 1 was developed by replacing the (Dividends)/Total Assets dependent variable with (Dividends)/Net Income. This version of the model is presented in column 4 of Table 4 , and its results show high compatibility with the previous three columns. Significant variables presented in the fourth column do not differ from corresponding coefficients found in the first, second and third columns. This shows that the dependent variable did not affect the study results or introduce bias.

However, further analysis is necessary, as mandatory minimum dividends may have influenced the results presented. Martins \& Novaes (2012) showed that mandatory minimum dividends in Brazil do not negatively affect firm investment levels and that this mechanism would not be harmful. To corroborate Martins \& Novaes' (2012) findings, a complementary model was generated to study companies that pay more than mandatory minimum dividends. Brazilian law requires that companies distribute at least $25 \%$ of their adjusted income in the form of dividends. Adjusted income records are difficult to access when only information provided in official statements is available. However, it can be concluded with reasonable accuracy that a company that paid more than $40 \%$ of its net income paid more than the minimum required amount. Based on this assumption, variables that affect very high dividend payments (i.e., $70 \%$ of net income) were evaluated to identify factors that cause companies to pay higher $(40 \%)$ and much higher (70\%) dividends than mandatory dividend levels. Two dummy variables with a value of one were created for payouts of above $40 \%$ and above $70 \%$. Columns 5 and 6 of Table 4 present the regression results, which are derived from a logit model for panel data. The results indicate that large companies are more likely to pay dividends above mandatory minimum levels, as the variable size was found to be significant at $1 \%$. Profitability (ROA) was also found to be a significant determinant of high dividends.

It is interesting to note that the Market to Book variable generated results that complement finance theories. Companies that pay high dividends accounting for less than $70 \%$ of net income levels have a positive coefficient that is significant at $1 \%$, confirming Lintner's (1956) hypotheses. However, companies that pay very high dividends (over $70 \%$ of profits) generate lower Market to Book coefficients at $10 \%$ significance.

Explanations for this result are directly linked to fi- nance theories, which state that such companies (1) are not engaged in adequate investment projects and thus distribute cash or (2) are experiencing a slow period but still maintain stable dividend levels, which is not well regarded in the market when it occurs repeatedly.

The overall liquidity variable remains positive and significant, showing that companies that pay high dividends ceteris paribus maintain higher current assets. In contrast to Market to Book cases, companies that distribute dividends of $70 \%$ exhibit greater liquidity, and thus, companies must ensure that such payments will remain constant in the future to be able to pay very high dividends. Liquidity ${ }^{2}$, as expected, showed a negative coefficient, indicating that high liquidity is not related to high dividend payments. Dividend coefficients in excess of 70\% (in absolute terms) suggest that high company liquidity correlates with lower company tendencies toward very high dividend payments. This suggests the existence of an optimal liquidity threshold for dividend payments, beyond which dividends start to decline as liquidity increases.

Profit Growth was found to have a significant positive coefficient for both dividend levels, suggesting that this variable has a favorable effect on high dividend payments. Again, Lintner's (1956) theories prevail, as managers only increase dividends when faced with consistent prospects of future company cash flow growth. Companies that pay more than $70 \%$ of dividends present lower growth rates, accounting for the high payment results given the likely decline in investment opportunities.

Poison Pills were found to have a significant negative sign, generating a higher coefficient for companies that pay dividends above $70 \%$. Hence, this clause, which maintains dispersed shareholding, helps managers retain company funds due to the lower propensity to pay dividends.

The 100\% Tag Along variable was also found to be negative and significant, as expected, indicating that this variable serves as a strong signal to investors while mitigating conflicts between controlling and minority shareholders. The variable thus accounts for part of the signal attributed to dividends.

Thus, Martins \& Novaes' (2012) findings are confirmed; that is, one cannot infer differences in dividend policies between companies that pay high dividends and those that pay dividends approaching the mandatory minimum.

\section{FINAL CONSIDERATIONS}

The objective of this study was to examine determinants of dividend policies among Brazilian public companies for the 1995 to 2011 period, thus addressing several gaps in the literature on dividends in Brazil.
The first research gap concerns methodological approaches. Tobit and GMM model results were compared. The Tobit model was suitable to employ in this work, as $34 \%$ of the observations studied included dividends 
equal to zero, given that OLS results may underestimate coefficients and/or overestimate intercepts under such conditions. To address issues of endogeneity, a recurrent theme in finance studies, the GMM estimator was employed, producing consistent coefficients in the presence of endogenous regressors.

A second gap in research concerns the extension of the econometric models currently used in studies on the determinants of dividend policy in Brazil. The present study thus examined market, governance and accounting variables, expanding results summarized by Martins \& Fama (2012), Heineberg \& Procianoy (2003) and Fonteles et al. (2012) on determinants of dividend policy in Brazil. The proposed model includes variables related to corporate governance, investment, risk, debt, signaling, agency conflict and liquidity to control for characteristic elements of the Brazilian stock market, and some of these variables had not previously been associated with dividend distribution policies in the Brazilian literature.

The following variable was selected after a review of national and international literature: Dividends/Total Assets as a response variable, and the following indicators were selected as explanatory variables: Size, ROA, Leverage, Market to Book, Liquidity, Capex, Beta, Profit Growth, Poison Pills, 100\% Tag Along and Listing Segments. An extended model with additional variables was also analyzed. The additional variables were Age, Majority Control and a dummy for cases in which the $\mathrm{CEO}$ and Board of Director Chairman duties were performed by the same person.

The overall analysis of Brazilian firm cash disbursement distribution determinants showed that significant positive variables include Size, ROA, Market to Book, Liquidity and Profit Growth. That is, it can be inferred from this study that larger firm size, profitability, market value, liquidity and profit growth levels correlate with a higher firm propensity to distribute cash to shareholders, supporting the theory of corporate finance. Significant negative variables include the following: Leverage, Liquidity Squared, Capex, Beta and 100\% Tag Along. These results also support existing literature findings on dividends. It can thus be concluded that companies that invest more heavily in fixed assets exhibit very high liquidity, leverage, and risk levels; less conflict between majority and minority shareholders; and a lower propensity to pay dividends to shareholders.

In the extended model, noteworthy variables with positive coefficients include the Majority Control variable and cases in which the CEO and Chairman of the Board roles are performed by the same person, further corroborating theories of corporate finance.
It was also noted that features of Brazilian legislation on dividends may have affected the results obtained, especially results concerning mandatory minimum dividends. Thus, the Logit method was used to examine the relationship between the same independent variables and payouts separated into higher levels (percentages) of dividend distribution (greater than $40 \%$ and 70\%) following Martins \& Novaes (2012). The following question was posed: How do dividend payments above the mandatory minimum affect the previously examined explanatory variables? Will the previous results, which are not distinguished by dividend level, be confirmed?

This segmented analysis of dividend levels produced the following results: significant positive variables include Size, ROA, Market to Book, Liquidity and Profit Growth, and significant negative variables include Liquidity $^{2}$, Poison Pills and 100\% Tag Along. Again, for the positive indicators, the existing literature on dividends was confirmed. This shows that larger firms of higher profitability, market value, liquidity and profit growth are more likely to distribute more funds (over $40 \%$ or $70 \%$ of the minimum required). The negative sign found for Liquidity ${ }^{2}$ suggests the existence of an optimal or peak liquidity level, beyond which companies restrict dividend payments to maintain it.

This study offers several contributions to the literature on determinants of dividend policy in Brazil, as it compares the empirical results of two econometric approaches, thus employing a methodological approach unprecedented in the literature that generated results consistent with national and international studies. This analysis was accompanied by a segmented examination of the highest dividend distribution levels based on specificities of Brazilian legislation. By revealing associations between dividend policies and firm financial decisions (investment, financing, available cash volume, capital structure, asset pricing, capital budgeting, etc.), this study presented factors that affect dividend policy in Brazil. Study limitations include a need for further theoretical understanding of equity interest and dividend uses for various ownership structures, such as pensions and family funds.

Future studies may employ a single corporate governance variable aggregated into a governance quality index to assess various CG mechanisms, thereby correcting possible multicollinearity issues between them without using separate variables, as was done in this study. This CG indicator would be used in regression models with dependent variables that represent dividends to more fully assess the relationship between these two constructs. 
References

Acharya, V. V. \& Viswanathan, S. (2011). Leverage, moral hazard, and liquidity. The Journal of Finance, 66 (1), 99-138.

Almeida, R. S. de. (2012). Governança corporativa: análise da composição do Conselho de Administração no setor de energia elétrica do Brasil. Dissertação de mestrado, Pontifícia Universidade Católica do Rio de Janeiro, Departamento de Administração, Rio de Janeiro, RJ, Brasil.

Barclay, M. J., Smith, C. W. Jr. \& Watts, R. L. (1995). The determinants of corporate leverage and dividend policies. Journal of Applied Corporate Finance, 1 (1), 4-19.

Barros, L. A. B. C., Junior, F. H. F. C., Silveira, A. D. M. \& Bergmann, D. R. (2010). A questão da endogeneidade nas pesquisas empíricas em finanças corporativas: principais problemas e formas de mitigação. [Working Paper]. Recuperado em 5 agosto, 2013, de http://ssrn.com/ abstract $=1593187$.

Bernardo, H. P. \& Ikeda, R. H. (2013). O enigma dos dividendos e o risco sistemático. Revista Universo Contábil, 9 (1), 104-120.

Black, F. (1976). The dividend puzzle. Journal of Portfolio Management, 2 (1), 5-8.

Black, F. \& Scholes. M. (1974). The effects of dividend yield and dividend policy on common stock prices and returns. Journal of Financial Economics, 1 (1), 1-22.

Boulton, T. J., Braga-Alves, M. V. \& Shastri, K. (2012). Payout policy in Brazil: dividends versus interest on equity. Journal of Corporate Finance, 18 (4), 968-979.

Brito, N. R. O. \& Rietti; R. C. (1981). Efeito clientela, níveis marginais de taxação e eficiência: o caso de dividendos no mercado acionário brasileiro. In N. R. O. Brito. (Org.). O mercado de capitais e a estrutura empresarial brasileira. Rio de Janeiro: [s.n].

Brito, R. D. \& Silva, J. C. (2005). Testando as previsões de trade-off e pecking order sobre dividendos e dívida no Brasil. Estudos Econômicos, 35 (1), 37-79.

Casey, K. M. \& Dickens, R. N. (2000). The effects of tax and regulatory changes on commercial bank dividend policy. The Quarterly Review of Economics and Finance, 40 (1), 279-293.

Dalmácio, F. Z. \& Corrar, L. J. (2007). A concentração do controle acionário e a política de dividendos das empresas listadas na BOVESPA: uma abordagem exploratória a luz da teoria de agência. RCO - Revista de Contabilidade e Organizações, FEARP/USP, 1 (1), 16-29.

Dickens, R. N., Casey, K. M. \& Newman, J. A. (2002). Bank dividend policy: explanatory factors. Quarterly Journal of Business and Economics, 41 (1), 3-12.

Fonteles, I. V., Peixoto Júnior, C. A., Vasconcelos, A. C. \& De Luca, M M. M. (2012). Política de dividendos das empresas participantes do índice dividendos da BM\&FBOVESPA. Revista Contabilidade Vista \& Revista, 23 (3), 173-204

Francis, J., Schipper, K. \& Vicent, L. (2005). Earnings and dividend informativeness when cash flow rights are separated from voting rights: Journal of Accounting and Economics, 39.(1), 329-360.

Futema, M. S., Basso, L. F. C. \& Kayo, E. K. (2009 janeiro-abril). Estrutura de capital, dividendos e juros sobre o capital próprio: testes no Brasil. Revista Contabilidade e Finanças, 20 (49), 44-62.

Gabrielli, M. F. \& Saito, R. (2003). Recompra de ações no Brasil: regulamentação e impactos sobre minoritários. Anais do Encontro da Associação Nacional de Pós-Graduação e Pesquisa em Administração (ENANPAD), Atibaia, SP, Brasil, 27.

Gompers, P. A., Ishii, J. L. \& Metrick, A. (2003). Corporate governance and equity prices. Quarterly Journal of Economics, 118 (1), 107-155.

Gordon, M. J. (1963). Optimal investment and financial policy. The Journal of Finance, 18 (2), 264-272.

Grullon, G., Michaely, R. \& Swaminathan, B. (2002). Are dividend changes a sign of firm maturity? The Journal of Business, 75 (3), 287-424.

Gu, Z., Lee, C. J. \& Rosett, J. G. (2005). What determines the variability of accounting accruals? Review of Quantitative Finance and Accounting, 24 (1), 313-334.

Heineberg, R. \& Procianoy, J. L.: (2003). Aspectos determinantes do pagamento de proventos em dinheiro das empresas com ações negociadas na BOVESPA. Anais do Encontro da Associação Nacional de Pós-Graduação e Pesquisa em Administração (ENANPAD), Atibaia SP, Brasil, 27

Hermalin, B. E. \& Weisbach, M. S. (2003). Board of directors as an endogenously determined institution: a survey of the economic literature. Federal Reserve Bank of New York Economic Policy Review, New York, USA.

Holanda, A. P. \& Coelho, A. C. D. (2012). Dividendos e efeito clientela: evidências no mercado brasileiro. RAE, 52 (4), 448-463.
Jensen, G. R., Solberg, D. P. \& Zorn, T. S. (1992). Simultaneous determination of insider ownership, debt, and dividend policies. The Journal of Financial and Quantitative Analysis, 27 (1); 247-263.

Jensen, M. C. \& Meckling, W. H. (1976). Theory of the firm: managerial behavior, agency costs and ownership structure. Journal of Financial Economics, 3 (4), 305-360

Jo, H. \& Pan, C. (2009). Why are firms with entrenched managers more likely to pay dividends? Review of Accounting and Finance, 8 (1), 87-116.

John, K. \& Knyazeva, A. (2006). Payout policy, agency conflicts and corporate governance. [Working Paper]. New York University.

Kania, S. L. \& Bacon, F. W. (2005). What factors motivate the corporate dividend decision. ASBBS E-Journal, 1 (1), 97-107.

La Porta, R., Lopez-De-Silanes, F., Shleifer, A. \& Vishny, R.W. (2000). Agency problems and dividend policies around the world. The Journal of Finance, 55 (1), 1-33.

Lintner, J. (1956). Distribution of incomes of corporations among dividends, retained earnings, and taxes. American Economic Review, 46 (2), 97-113.

Loss, L. \& Sarlo Neto, A. (2003). Política de dividendos, na prática, é importante? Revista Contabilidade \& Finanças, São Paulo, Edição Comemorativa, 39-53.

Martins, A. I. \& Famá, R. (2012). O que revelam os estudos realizados no Brasil sobre política de dividendos? Revista de Administração de Empresas, 52 (1), 24-39.

Martins, T. C. \& Novaes, W. (2012). Mandatory dividend rules: do they make it harder for firms to invest? J. Corp. Finance. doi:10.1016/j. jcorpfin.2012.05.002

Mayne, L.S. (1980). Bank holding company characteristics and the upstreaming of bank funds: Journal of Money, Credit and Banking, 12 (2), 209-214

Miller, M. \& Modigliani, F. (1961). Dividend policy, growth and the valuation of shares. Journal of Business, 34 (1), 411-433.

Miller, M. \& Scholes, M. (1982). Dividends and taxes: empirical evidence. Journal of Political Economy, 90 (1), 1118-1141.

Moh'd, M. A., Perry, L. G. \& Rimbey, J. N. (1995). An investigation of the dynamic relationship between agency theory and dividend policy. The Financial Review, 30 (2), 367-385

Mota, D. C. (2007). Dividendos, juros sobre capital próprio e recompra de ações: um estudo empírico sobre a política de distribuição no Brasil. Dissertação de mestrado, Programa de Pós-Graduação em Administração de Empresas, EAESP-FGV, São Paulo, SP, Brasil.

Novis Neto, J. A. \& Saito, R. (2003). Pagamentos de dividendos e persistência de retornos anormais das ações: evidência do mercado brasileiro. Revista de Administração da USP, 38 (2), 135-143.

Paiva, J. W. \& Lima, A. V. (2001). A influência da tributação e dos juros sobre o capital próprio na política de dividendos das companhias brasileiras. Anais do Encontro Brasileiro de Finanças, SBFin, São Paulo, SP, Brasil, 1.

Renneboog, L. \& Trojanowski, G. (2011). Patterns in payout policy and payout channel choice. Journal of Banking \& Finance, 35 (6), 1477-1490.

Rozeff, M. S. (1982). Growth, beta, and agency costs as determinants of dividend payout ratios. The Journal of Financial Research, 5 (1), 249-259.

Setia-Atmaja, L., Tanewski, G. A. \& Skully, M. (2009). The role of dividends; debt and board structure in the governance of family controlled firms. Journal of Business Finance \& Accounting, 36 (7-8), 863-898.

Speranzini, M. M. (1994). Efeito da política de dividendos sobre o valor das acões no mercado brasileiro de capitais. Dissertação de mestrado, Faculdade de Economia, Administração e Contabilidade da Universidade de São Paulo, São Paulo, SP, Brasil.

Vieira, J., Martins, E. \& Fávero,.L. P. L. (2009). Poison pills no Brasil: um estudo exploratório. Revista Contabilidade \& Finanças, 20 (50), 6-24

White, H. (1980). A heteroskedasticity-consistent covariance matrix estimator and a direct test for heteroskedasticity. Econometrica, 48 (4), 817-838, http://EconPapers.repec.org/RePEcrecm:emetrp:v:48:y:1980 :i:4:p:817-38

Correspondence Address:

Cristiano Augusto Borgi Forti

Faculdade de Gestão e Negócios, Universidade Federal de Uberlândia Avenida João Naves de Ávila, 2121 - CEP: 38400-100

Campus Santa Mônica - Uberlândia - MG

E-mail: forti@fagen.ufu.br 